\title{
Frank Ankersmit and Eelco Runia: The Presence and the Otherness of the Past.
}

\author{
Anton Froeyman ${ }^{*}$ \\ Centre for Critical Philosphy, Ghent University, Belgium
}

\begin{abstract}
This paper consists of two parts. In the first part, I give an in-depth comparison and analysis of the theories of Frank Ankersmit and Eelco Runia, in which I highlight their most important resemblances and differences. What both have in common, is their notion of the presence of the past as a "presence in absence". They differ, however, with respect to the character of this past and the role representation plays in making it present. Second, I also argue that for both Ankersmit and Runia, the presence of the past is always the present of our past, which excludes the experience of the otherness of the part, and which opens both theories to the criticisms of being self-centered and nationalistic.
\end{abstract}

Keywords: Ankersmit, Runia, Levinas, Presence, Representation, Otherness

In the course of the last decade there has been an increasing feeling of dissatisfaction with the postmodern and post-structuralist paradigm among many theorists of history. (see for example Palti 2004; Agnew 2007; Bentley 2006) The main objection is the that the focus on the creation of meaning and representation has led to the loss of the object of the historian or the philosopher of history rather than to its revelation or affirmation. In response to this dissatisfaction with the postmodern and poststructuralist paradigm, several alternative approaches have turned up which all share the same aim. They try to rethink our relation with the past as a more real, direct, material and affective one. Their common project is to make the past present again, not as an ideological or tropological construction, but as the past itself, whatever this may mean. The basic problem which these new philosophies of history face is "how can we think of history as something real, without being a naïve realist or a naïve empiricist?

There are many people who have formulated methodological suggestions and theoretical considerations in this direction. (see for example Jones 2000, 2007, 2008, Gumbrecht 2003, 2004, 2006; Abbott 2007; Philips 2008) At this point, many of these suggestions are more or less fragmentary and not really systematic. There are, however, two exceptions. The first is Frank Ankersmit's theory of (Sublime) Historical Experience. The second is Eelco Runia's theory on "presence". Ankersmit and Runia's theories are often placed under the same banner of post-poststructuralism and post-postmodernism. To a certain extent, this is justified, since both obviously share a common goal, namely the ability to think and talk about the "past itself" without resorting to naïve realism. (whether they succeed in doing this is, of course a matter of debate) Nevertheless, there are some important differences which very often go unnoticed. The first aim of this paper then is to highlight these differences. My

\footnotetext{
*E-mail: anton_froeyman@yahoo.com
} 
second aim here is to make some remarks with regard to the scope of both theories. I will claim that both theories rule out an aspect which is of vital importance is some of the major traditions of how we deal with the past, namely the "otherness" of history.

\section{Ankersmit vs Runia}

In this part, I will make a comparison between Ankersmit and Runia by focusing on the role of three concepts which are essential to any theory of historical writing. These concepts are "subject" (the historian herself) "object", (history itself, whatever this may mean) and "language/text/symbolization" (which mediates between subject and object) Most if not all essential differences between theories of history are rooted in different conceptions about the interrelation between these three concepts. Of course, this does not mean that all three are things in themselves. For most theories, each is more or less embedded in the other two. Nevertheless, there are significant differences in what they are considered to be and how they are embedded in each other. The challenge for philosophers such as Ankersmit and Runia consists of giving an answer to the question of how we can relate to the object of history, the past itself, without falling into the trap of naïve realism. They need an account which does not presuppose that there is a past independent of us which we can gain access to by means of language, and which still claims it makes sense to talk of the past itself, independent of our linguistic representations.

\subsection{Ankersmit}

Frank Ankersmit's theory of historical experience has developed during the last twenty years, and it is not easy to pin down. Ankersmit uses an eclectic variety of theories and influences. The result is that his theory appears in different varieties and that there is no definitive version. Nevertheless, there is are certain constant factors.

\subsubsection{The Basics}

From narrativism to presence. In (Moskalewicz 2007), Ankersmit makes it clear that the theoretical starting point of his turn towards experience was Richard Rorty's dismissal of epistemology as a doubtful enterprise. (Moskalewicz 2007, 252) In the introduction of Sublime Historical Experience, Ankersmit states that the novelty of his notion of experience lies in the separation of experience from truth (and therefore epistemology). (Ankersmit 2005, 9) Ankersmit's most concise and clear formulation of the problem goes as follows:

Now, as I said a moment ago, what you have in all epistemologies is this relationship between a knowing subject, on the one hand, and a part of the world, on the other. And then I had the, rather obvious idea that what you have between the subject and the object-is, of course, experience. For if the subject does have knowledge of the world, succeeds in obtaining knowledge of the object, then it's experience enabling him to have this. So, I began to understand that if I wanted to get away from epistemology, and to do what Rorty had failed to do, I should focus on this notion of experience. But the problem is that there is a very obvious notion of experience, the kind that you 
find in empiricism, and which perfectly fits within the traditional epistemological model. So turning to experience is not sufficient; empiricism is, after all, also a form of epistemology. So what I was looking for was a kind of experience which would somehow move us out of this empiricist model, and where things would be possible that are impossible in the epistemological and the empiricist model. (Moskaliewicz 2007, 252-253)

The basics of Ankersmit's proposal for a new kind of philosophy of history consist of a new conception of how subject and object relate to each other. While the received view in theory of history takes language to be the tertium by means of which subject and object are able to relate to each other, Ankersmit believes that experience is fundamental to language and that, therefore, experience is the fundamental mediator between subject and object. Of course, this is a conceptual leap for which no real argumentation can be given. Rather, one should see it as a proposition to change one's perspective more than as a logical demonstration.

Moreover, Ankersmit also believes that the kind of experience we are dealing with in history does not have anything to do, at least not in a direct way, with truth. Ankersmit's most interesting paper in this respect is (Ankersmit 2000). Here, he argues for an alternative view on the relation of subject and object in historical and aesthetic representation, much along the lines of the narrativistic Ankersmit as in (Ankersmit 1983) and (Ankersmit 2001b). Yet he also makes clear how this conception of the relation between subject and object is related to experience. The general claim can be summarized as follows.

Put differently, my point of departure will be the conviction that an important step towards a correct understanding of the notion of representation will have been made as soon as one realizes that the relationship between a representation and what it represents is essentially different from the relationship between a true statement and what it is true of. (Ankersmit 2000, 149)

At this point, the new Ankersmit is still in line with the old one, as well as with Haydn White and most postmodernists. The general argument in this paper is that there is a qualitative difference between singular statements such as "the cat is on the mat", and more complex representations which we can find in art and history. The difference is that singular statements can simply be true or false, while historical and aesthetic representations cannot. They should rather be considered as proposals to regard the facts in a certain light. (Ankersmit 2000, 152; see also 1983, 248-249) They cannot be true or false, only original, boring, interesting... This qualitative difference between singular statements and complex representations also has a consequence for the relation between subject and object. Take the following statement.

Suppose we compare a picture (or even only a photograph) of Marlon Brando in which Brando looks surly with the statement "Brando is surly". In the case of the statement, we distinguish clearly and unambiguously between the 
subject-term and the predicate-term and, hence, between what the statement refers to and the property being attributed to it. No such distinction is possible in the case of the picture or photograph; we cannot divide the picture into two parts, of which the former corresponds to Brando and the other, to the surliness attributed to him. Referring and attribution always go together in the picture (Ankersmit 2000, 154)

In short, in historical and aesthetic representation, there is a much more intimate relation between subject and object than in the case of true singular statements, which are dominated by epistemology. Peter Icke (2010) has recently highlighted the crucial role of the concept of narrative substance. In a narrative substance, what we talk about as historians and how we talk about it (i.e. how we represent) are essentially intertwined. This implies, as Icke correctly observes, that historical reality, understood as the subject-matter of the scientific discipline of historiography, is always permeated by language and cannot be seen as a thing in itself, independent of anyone's point of view. So far, so good.

Now, the crucial conceptual leap which distinguishes the new Ankersmit from the old one is the following: because of the specific nature of historical representation, there is also a specific kind of historical experience, which, just as historical representation, is not susceptible to epistemology. This is the point where the narrativistic Ankersmit turns into the presentist Ankersmit and where postmodernists such as Icke stop following him, since it implies a notion of experience independent of language and symbolization. Their idea is that Ankersmit opens the door for a direct access of the historian with the past itself, independent of the language and representation. This would turn the clock of philosophy of history back to the era before the linguistic turn and that, after Derrida, Foucault and so many others, this is an untenable statement.

Peter Icke for example states in (Icke 2010), following the narrativistic Ankersmit, that historical reality, the result of historical enquiry, is always constituted from a specific, personal point of view, and can therefore never claim to be a copy of the past itself. I whole-heartedly agree. Nevertheless, this has little to do with the kind of historical reality the presentist Ankersmit talks about. Of course, every historical representation is constituted from a personal and subjective point-of-view, as Icke states. But points-of-view are not isolated things in themselves, created by free and independent subjects. Points-of-view are created by context, i.e. by power relations, by social norms, by education, by symbolic conventions,... In short, they are constituted by history. This results in a circle. We create historical reality through our subjectivity, but our subjectivity is in its turn created by history itself. Therefore, if we do not want to end up In a vicous (or a Hegelian) circle, historical reality as we constitute it and the historical reality which constitutes us cannot be considered to be exactly the same. This is exactly what Ankersmit states: there is a relationship with the past which is different from our constituted historical representations. We do not have access to this past through our use of concepts and language, since this past is exactly what constitutes the concepts which determine our point-of-view. The same 
goes for experience. We cannot experience the past as a traditional transcendental percieving subject, since the past is what determines the structure of our experience in the first place. It is because of this that Ankersmit refers to historical experience as "experience without a subject of experience", a kind of mystical unification rather than a conscious percpetion, which is better expressed as Erlebnis than as Erfahrung or Anschaung.

Icke and many others (including one of the referees appointed by Rethinking History) take Ankersmit's account of historical experience to be competing with his earlier notions of historical representation and narrative substance. This is a misunderstanding. When Ankersmit talks about historical experience, he is talking about the past as it constitutes us. When he talks about historical representation, he is referring to historical reality as we constitute it, which is something completely different. Keith Jenkins is one of the few who have really paid attention to this specific point (Jenkins 2008a, 538-539) Historical representation is the end-point of historical enquiry, and historical experience its beginning. This means that Ankersmit's two theories, one (the earlier) of representation and the other (the later) of experience, have a different intention. While his theory of historical representation can give a historian some guidelines on how to write history, sublime historical experience cannot. The aim of the latter is rather to make a historian understand why she has become a historian on the first place, and what the relation is between her position as a historian and the society she lives in.

The presentist Ankersmit The precise nature of this specific experiential relation between the subject and object of historical representation is the main subject of Ankersmit's publications from the early 1990's until the present day. The essential feature of this experiential relation is its paradoxical nature. In his inaugural lecture, Ankersmit refers to historical experience as the "improbable probability" of our relation with the past, the realization that something is both impossible and yet still real. (see Ankersmit 1993, 24) We encounter this general idea throughout his work starting from the 1990's. The best way in which we can describe this is by calling it a "presence in absence". According to Ankersmit, the past can be overwhelmingly present precisely because it is absent. Because the past is absent from our representational categories, it can be present in our inner selves, in a much more direct way than if it were represented.

Ankersmit makes this clear by means of an analogy with patients suffering from de-realization, who experience themselves as sitting under a cheese-cover and being cut off from the world. Precisely because they realize that they are under such a cover, the outside world appears as threatening and unbearably real. If they, as normal people do, would not realize they were under the cheese-cover of language and representation (of which their own cheese-cover is an objectification), reality would not appear in such a threatening way. In short, patients suffering from de-realization have both a more and a less direct contact with the world. On the one hand their contact is less direct, because they feel separated from the world by the cheese-cover. On the other hand, it is more direct: precisely because they are conscious of their 
cheese-cover, they can see the terrifying possibility of a direct and unmediated contact with reality. (Ankersmit 2001b, 310-311)

Ankersmit now states that this is the way historical experience works. It arises when we discover something from the past which does not fit in the cheese-cover of conceptual schemes and which therefore refers to a reality which is forever hidden. However, precisely because we know this past to be unattainable and we still know it has to be there, a double feeling is aroused: a paradoxical experience of loss and love (Ankersmit 2005, 9) This kind of experience is, according to Ankersmit, an "experience without a subject of experience" (Ankersmit 2005, 222-228) If the subject plays a part, it is only a passive one. (Ankersmit 1993, 13) Nevertheless, this does not mean that Ankersmit believes that historical experience is objective in the sense of "necessarily the same for every subject", which one might suspect if one rules out subjectivity as a positive influence. On the contrary, historical experience is deeply subjective, but only in determining its occurrence, not its content. Whether or not a person undergoes a historical experience depends strongly on this person's tradition and context. What the historical experience will be like, however, is entirely up to the past itself. (Ankersmit 2000, 160; 1996, 71)

\subsubsection{The specifics: Huizinga, Trauma and the Sublime}

Huizinga. As already said, there is a certain basic theoretical structure in Ankersmit's writings on historical experience which remain constant in his work in the last two decades. First, there is the idea of the possibility of experience of the past which is non-epistemic, non-linguistic and decontextualizing. As already said, this theoretical move is not an argument, but rather a conceptual leap of faith. The second basic idea is that this kind of experience is essentially paradoxical: it is a presence in absence. We can experience the past not despite, but exactly because it is not ready-to-grasp in front of us. Historical experience is constituted by a continuing struggle between presence and absence. The most obvious way to interpret this is to say that the past is present in our experience and absent in our representational categories, which of course presuppose the first point of the possibility of a non-conceptual kind of experience.

So far, so good. The difficulties concerning Ankersmit's work arise when we want to know a bit more about these two basic ideas. Exactly in what sense can an experience be non-linguistic? What is absent in historical experience, and what is present? And how do presence and absence relate exactly? If we look at Ankersmit's oeuvre, there is no single definite answer. Instead, there are two answers, which are actually quite different from each other. Each of these two is born from a specific inspiration.

Ankersmit's first source is Huizinga's notion of "historical sensation". (Ankersmit 1993, 11-12; 1996, 50-51) In the traditional Kantian sense, "sensation" denotes our disparate impressions, while experience denotes a structured unity of such impressions. Experience in this sense requires a certain (conceptual) organizing principle. Huizinga, however, uses a totally different concept. Huizinga 
was heavily influenced by the "Eighties Movement" most importantly Lodewijk Van Deyssel. (Huizinga VII, 166) These poets united around the idea that language could evoke a direct and unmediated experience of reality. This kind of experience or sensation is uncompromisingly anti-Kantian. It has more to do with concepts such as Entschlossenheit (Heidegger) or Epiphany (Levinas), and it is strongly related to mysticism.

Huizinga talks about historical sensation at two different places. In the first (Huizinga II, 559-569), he defends the idea that history can have a use which is beyond knowledge. According to Huizinga, history can arouse a kind of spiritual enjoyment similar to, but not the same as, artistic experience. Therefore, he pleads for the establishment of a specifically historical museum, devoted to the arousal of historical sensation. This museum should not be stuffed with the great works of art history or remembrances of the actions of great men. Historical sensations are aroused by seemingly insignificant objects, which look as if they are stolen from the daily life of the people of the past. Contrary to artistic experience, there is nothing special about these objects in themselves. They draw their special qualities from the fact that they seem out of place, and this-out-of-placeness triggers our imagination. (see Huizinga II, 571) According to Ankersmit, this experience of anachronism, of something of a different time being present in our own, causes a double de-contextualization. On the one hand, the object is out of place since it is from another time, while on the other the subject is out of place as well, since in the confrontation with another time it temporarily loses itself and cuts itself loose from its familiar surroundings.

Something similar is also stated in Huizinga (VII, 69-73). Here Huizinga argues against Karl Lamprecht and his universalistic view on the writing of history and sides with Rickert and Dilthey in their defence of historical contingency. Yet Huizinga also criticizes Dilthey and Rickert for their too realistic and too "presentist" conception of Nacherleben.('reliving') According to Huizinga, our contact with the past is not a re-creation of "the real thing". He describes it rather as a dream-like experience where the past seems at the same time ready-at-hand and infinitely far away. He stresses the fact that historical sensation is not simply an experience of the past itself, but rather the experience of being almost in a direct contact with the past, yet not completely. (Huizinga VII, 72) What is specific to a historical sensation according to Huizinga is exactly that we are not in a direct contact with the past, that we realize that this is impossible, but that we still have the feeling that we are almost there.

In summary, by taking over Huizinga's concept of historical experience, Ankersmit does indeed give some details on the non-linguistic character and the paradoxical nature of historical experience. Historical sensation is a special kind of experiencing from everyday material objects from the past, somewhere in between mysticism and aesthetics. This kind of experience is possible because these seemingly unimportant objects are not thematized in our historical discourse. We get the feeling of experiencing the past itself rather than somebody's representation, simply because no professional historian has ever bothered to take up these objects as a theme of a 
historical representation. The non-thematization of historical objects also brings the element of absence in the presence of historical objects. Precisely because they are not thematized, we cannot contextualize them, and we can never understand or know them completely.

Trauma \& the sublime. In Ankersmit (2001b), Ankersmit introduces two new concepts. These two concepts are trauma and the sublime. It is true that Ankersmit already refers to the sublime before 2001, but he gives it a very special meaning from the moment he connects it with trauma. The fact that Ankersmit links his theory to trauma is quite natural. What is essential about trauma is that the past is experienced in a way which is both less and more real than in a normal situation. It is less real, because the patient is not conscious of her past and cannot represent it. On the other hand, it is more real, because it has a much more profound influence on the patient than any meaningful event out of our normal "represented" past could ever have. Trauma, in short, fits perfectly well within Ankersmit's idea of historical experience as an experience of presence in absence.

In the traditional view on trauma (Ankersmit calls this trauma1), there can be a reconciliation between the conscious and the unconscious, or, in other words, between the present and the past. This can only happen by means of a dialogue with an external factor, for example a therapist. However, Ankersmit introduces a less orthodox form of trauma (trauma2) in which the tension cannot be solved, simply because there is no external factor.(Ankersmit 2005, 324-325) He associates this with a change of identity of civilizations caused by revolutions. (Ankersmit 2001b, 301; 2005, 323) This makes trauma2 typically a collective form of Trauma. In (Ankersmit 2001b), Ankersmit refers to trauma2 as "sublime dissociation if the past". (Ankersmit 2001b, 314-310) In (Moskalewicz 2007), Ankersmit confirms that he takes sublime historical experience to be collective while what he calls the Huizinga-type of historical experience is involved with the formation of a strictly individual new identity. (Moskalewicz 2007, 259) Later on in this paper, I will show that this equation of sublime historical experience with collective trauma-like experiences has an important consequence with respect to the scope of his theory.

Ankersmit's involvement with Huizinga's nostalgic notion of historical sensation and the concept of trauma have been a great disappointment to Keith Jenkins. Jenkins states that this results in the end in a conservative, pessimistic and gloomy view (Jenkins 2008a, 548), and he prefers the anarchistic and light (in the Nietzschean sense) Sande Cohen and Lyotard to Ankersmit because of this. (see Jenkins 2008a, 2008b, 2008c) The "radical historian" resulting from his view would have an continuously emancipating and disturbing role towards the society she inhabits, while the Ankersmitian historian would not be of any real use. This is an important point, but it would not bother Ankersmit. Ankersmit is a conservative, and Jenkins a progressivist, which is very clear in his description of the social role of the radical historian. (Jenkins 2008b) It is obvious that Ankersmit's view seems pessimistic to Jenkins, because for a progressivist it is impossible to see how a nostalgic longing for a bygone past can be a source of joy. It is also obvious why Jenkins believes that an 
Ankersmitian historian can be of no use for society, since she would have no emancipating and liberating potential. But this is exactly Ankersmit's point. The social "use" of an Ankersmitian historian would not be to encourage change, but to prevent it. Good historians would withhold anarchists such as Cohen, Lyotard or Jenkins of changing society all too rashly and would stress the enduring value of traditions. What Jenkins denotes as a problem with a "cast of mind" (Jenkins 2008a, 539) with Ankersmit's notion(s) of historical experience, is really something else, something much more fundamental, namely a political problem. My point here is not that this criticisms are unjustified. On the contrary, the fact that Jenkins' criticisms seem to be originating from a political disagreement rather than a certain difference in 'cast of mind' makes them all the more relevant.

\subsection{Runia}

Like Ankersmit, Runia pleads for a return of the real within philosophy of history. Runia draws his inspiration for his theoretical search for historical reality from what might seem an unexpected source, namely Lev Tolstoj's "War and Peace", the subject of his PhD dissertation. (Runia 1995) What Runia appreciates in Tolstoj are his descriptions of historical battles, unheard-of in Toltstoj's time. Instead of the character of generals, strategic troop movements and tactical decisions on the battlefield, Tolstoj describes historical battles from within. These descriptions unmask all talk about tactics as mere story-telling and reveal the battle as it really was: a literally indescribable chaos. This theme is repeated throughout "War and Peace". People constantly distort what really happened by telling stories about it and by fitting it into predetermined representational schemes. What really occurs is either to traumatic or to vulgar to be told as it happens. Runia is fascinated by this theme, and his whole theory can be seen as a series of attempts to find a way in which the untellable historical reality, of which the historical battle is the archetype, can be told. His second book (Runia 1999) is an exploration of the non-discursive reality of history and a search for means in which this non-discursive reality can be recreated. Not coincidentally, two of the three canonical events Runia investigates in this book are battles.

Besides "War and Peace", there is Runia's own experience as a psychoanalyst. This is, again, not a coincidence. One of the fruitful things about (Lacanian) psychoanalysis is that it offers us a concept of the "real" which is independent of traditional epistemology. According to Lacanian psychoanalysis, the real is what is outside of language and which cannot be assimilated into a symbolic system. The "real" is impossible, but still real, hence its traumatic quality and hence also its character of a presence in absence. Lacan of course does not refer to the real as an ontological "thing". Rather, the order of the real is one of the three orders by means of which the subject relates to being. (Evans 1996, 162) Because there are different orders, the subject itself is also differentiated. At any given time, it is involved in one of the three orders, and excluded from the others. Because of this, the subject is always a split subject. 
According to Lacan, the subject is split from the moment it speaks. As a result of its participation in the symbolic system, it is cut off from the possibility of a complete knowledge of itself. (Evans, 1996, 192) The "I" consists of an articulated and a nonarticulated (or representable and non-representable) part, which are not necessarily in harmony with each other. Runia also claims that the unconscious part is much more essential than we like to think it is. The uneasy consequence of this is that we as individuals or subjects do not have privileged access to ourselves. Runia refers to Daryl Bem's self-perception theory to clarify this. (Runia 2010, 12; 2007, 319) According to Bem, individuals do not derive their knowledge about themselves from somewhere "within", but only by external means, i.e. by observing their own actions, which really amounts to constantly posing the question "what person am I, considering that I do the things I most obviously do?" Our conscious self constantly tries to catch up with our unconscious self. (see also Runia 2007, 319) This is a frightening realization. It implies that at any given time our idea of who we are, our whole identity, can be proven to be wrong or inadequate with respect to our deeds. It implies further that we never fully understand ourselves. On the contrary, what we do not understand is more fundamental for what we are than what we do understand.

"We are what we don't understand, we can understand what we are not". (Runia 2006b, 21)

Because of the Lacanian definition of the real and the principle of the split subject, Runia is able to give an account of reality which goes beyond traditional epistemology. The reason is that the traditional subject-object distinction, which is essential to traditional epistemology, is replaced by a distinction "within" the subject itself, or, more correctly, between two different ways in which the subject engages with the outside world. One is discursive, mediated and conscious, the other unmediated and unconscious.

In Runia's theory, this doubleness of the subject shows itself in two different ways, which we could label as an active and a passive manner.(see Runia 2006b, 6-7) In the passive sense, it is articulated in the concept of "presence", while in the active sense, it comes down to the notion of the sublime historical action. I will discuss Runia's concept of presence first, followed by his views on the sublime. Runia introduces his conception of "presence" in (2006b) He first describes it in a negative way, by contrasting it with "meaning", and then positively defines it in the following way:

"Presence," in my view, is "being in touch" - either literally or figuratively — with people, things, events, and feelings that made you into the person you are. It is having a whisper of life breathed into what has become routine and clichéd-it is fully realizing things instead of just taking them for granted. (2006b, 5) 
It is obvious that the idea of presence has a lot in common with Ankersmit's notion of historical experience. It involves the same conceptual leap to a notion of experience which is completely independent of language. Just as Ankersmit and Huizinga's notions of historical experience and historical sensation, we are dealing with a short moment that breaks through our everyday routine and which gives us a feeling of a direct contact with the past. One of the big differences, however, is that in Runia's theory the past can and often will be present at an unconscious level. The subject of an Ankersmitian sublime historical experience knows very well what she is undergoing. The subject of presence does not. The best example is Runia's analysis of the parallel processing involved in the report of the Srebrenica commission. (Runia 2004) In Runia's formulation, "parallel processing" means the following:

Dominick LaCapra has remarked that "when you study something, at some level you always have a tendency to repeat the problems you are studying." From a theoretical as well as a societal point of view, parallel processes are important manifestations of this tendency. Broadly speaking, a parallel process is going on when difficulties experienced in one environment are replicated in another environment. The concept originates in psychoanalytic supervision, is used in medical and psychotherapeutic settings, and refers, typically, to instances in which problematic interactions between residents and their patients are mirrored in the teaching encounter, in, that is, the interaction between residents and their tutors. System theorists speak in this respect of "isomorphism" - a term borrowed from mathematics. (Runia 2004, 297)

Runia argues that this was indeed the case in the study of the behaviour of the Dutch soldiers at Srebrenica studied by the historians of the Sreberenica comission. He lists seven structural similarities between the Dutch soldiers in Srebrenica and the historians, partly due to circumstances, but partly actively (but still unconsciously) created by the historians themselves. The general point is that these similarities made the Dutch historians "act out" the actions of the Dutch battalion. They refused to take a point view, tried to deafen the discussion behind an overly detailed report, and used the same argumentation as the battalion itself to keep the responsibility away from the solders. (Runia 2004, 296-297) In this way, the past comes back into the present, unconsciously, but with greater consequences than the represented past could ever have had. Of course, this kind of argument stands or falls with the identification of the historians with what they are studying. While this claim has, in my opinion, some plausibility in the case of the Sreberenica commission, this is much less so in Runia's other notorious example of "presence", namely the torturing practices in Abu Ghraib, where Runia believes that the "presence" of the prison itself in some mysterious way made the American soldiers torture their prisoners. This only shows that the idea of "presence" becomes very misty when it is cut loose from psychological processes of identification. This marks an important difference with Ankersmit. As we have seen, Ankersmit describes both sublime historical experience and historical sensation as conscious states of mind, as a longing towards the past as a lost paradise, comparable 
to nostalgia. The past itself seems attractive, but the experience of distance, of not being able to bring it back, arouses a historical experience. In Runia's account, however, there is no conscious longing for the past. On the contrary, the past is too terrible and chaotic to represent, and it forces itself upon us and makes us behave in a certain way, outside of our control.

A second important difference between Ankersmit and Runia concerns the role of representation in the arousal of presence and historical experience. As we have seen, Ankersmit follows Huizinga in stating that historical experience involves a double decontextualization. Both subject and object are, just as Romeo and Juliet, removed from their context in order to meet each other somewhere in between. This is the case both in the Huizinga-type of historical sensation as in (sublime) historical experience. In Runia's account things are different. According to Runia, the past actually uses our context in order to achieve its presence. It behaves as a "stowaway". (Runia 2006b, 27; Runia 2006c, 315) Historical reality "attaches itself", so to speak, to our modern (historical) representation, to a large extent in the same way as a computer virus can attach itself to an e-mail. Despite their intertwinement, however, there still is a certain kind of trade-off between presence and representation. (Runia 1999, 21) The more extensive and complicated a symbolic system is, the less presence has a chance of breaking through. This explains why, according to Runia, simply reciting the names of Holocaust victims has a much more intense presence-effect than any sophisticated representation of the Holocaust could ever have. (Runia 2006a) Runia clarifies this by referring to metonymy. In the use of metonymy we name only one aspect, but by doing so, we implicitly call up a whole array of other traits. Because these other features are called up implicitly and therefore pass through a "thinner" part of our representational scheme, they give the impression of being more real and less affected by this representational scheme. Nevertheless it should be noted that, as Runia himself clearly says, metonymy itself is not an instance of a presence-effect, but only a metaphor in order to understand the theory. (see 2006b, 6)

In the active sense, the split-subject principle allows for a special kind of historical agency, an idea which Runia develops in. (Runia 2010) Runia takes over the notion of the sublime from Ankersmit, but gives it a very different meaning. He argues that historical action sometimes take the character of a "vertigo", a combination of three things: a rational and discursive unwillingness to jump, an unconscious will to jump anyway and, most importantly, the fear that the second urge will be stronger than the first. Runia claims that, by looking at history through the eyes of the vertigometaphor, he is able to "account for those mind-boggling and sometimes extremely bloody events in which we enter something really, sublimely new." (Runia 2010, 1) The difference now between Ankersmit and Runia's account of the sublime is really a difference in levels of description. As we have seen, in Ankersmit's account, the sublime is used as a model for the relationship between the historian and the past. In Runia's account, however, the sublime is a conceptual "tool" by means of which a historian can make sense of historical actors. As a consequence, concerning Runia's theory in general, the sublime seems to belong more in the methodology of history, as a principle which historians can use to understand the ununderstandable as it has 
manifested itself in the past. This leaves aside the question of the position of the historian herself, while "presence" as a concept has its place in philosophy of history, as an analysis of the relation between the historian and the past.

\section{The Present of who's Past?}

In this section, I will claim that both discussed theories cannot accommodate some important ways in which we in the West deal with the past. All three concern an experience of the past as an experience of otherness, or, in more familiar words, the famous topos "the past is a foreign country". The otherness of the past should be distinguished from historical distance. Historical distance refers to the fact that, simply said, there is a rupture between the present and the past and that the past is therefore different from the present. For example, the ancien régime is different from modern capitalist society. Nevertheless, it is still a different version of the same society we live in, and it is this fact which draws our interest. What I call the "otherness" of the past, however, refers to the fact that the past can be perceived not as an earlier version of the present, but as something essentially different. While in historical distance the past is an earlier time, in the otherness of the past the past is a different time. The kind of experience associated with this otherness, the experience of the past being an altogether different time, is a priori excluded from Ankersmit and Runia's theories. This is not necessarily a critical point of view in the negative sense, since Ankersmit nor Runia explicitly pretend to give an all-encompassing theory. Ankersmit even explicitly denounces this claim (Moskalewicz 2007, 260-261) Nevertheless, it is a vital point with respect to the scope of both theories.

Our first case is the exoticism present in historical tourism. It has been amply argued that the desire for the experience of otherness is one of the basic motivations of modern tourism in general. (see for example Culler 1989, 167; Cohen 2004, 318; MacCannell 1999, xxi; Alexander, Bakir \& Wickens 2010) It is quite obvious why this has to be the case. Tourism is a very inefficient way of gathering knowledge compared with reading a book or following a history class. So what else could be the objective of historical tourism than a special kind of historical experience of "the real thing"? (see Runia 2007, 313-314) Therefore, one would expect that Ankersmit and Runia's theories, as theories which treat the past as an experience of the real thing in its non-cognitive aspects, would be very suitable for an analysis of historical tourism

Second, the experience of otherness is also present in professional history-writing, most significantly in microhistory. Microhistory does not contribute significantly to the total body of knowledge about the past, nor about human behaviour in general: microstorie are about small-scale and local phenomena which did not have much influence on the course of history and from which it is very hard to derive general laws about human behaviour. Therefore, if the aim of micro-history would be to confer relevant knowledge, it would be a very inefficient enterprise. If, on the other hand, we state that its purpose is to convey lived experience, its contribution becomes undeniable. (see Szijarto 2002, 210-212; Philips 2008, 62) Furthermore, micro-history is never about identification in the way national history is. Microhistorians tend to focus on outsiders, people who fall through the net and who cannot really be seen as 
representative for a certain social group, in the past nor in the present. Therefore, it can be seen as an enterprise which aims to unearth the otherness of the past.

Third, there is a moral aspect of the presence of the other in history. It concerns the representations of minorities in the writing of history. If historians would limit their interests to what and who they can identify with and what is relevant for themselves, they are in danger of underrepresenting all kinds of minorities. In doing this, they would simply reproduce the current state of society. The traditions of subaltern history, postcolonial history, gender history, etc are witnesses to the fact that this is not the current state of affairs in professional history-writing. The incorporation of minorities in history as others instead of enemies or incomplete versions of one's own social group is arguably the biggest merit of the postmodern and postcolonial paradigm. It is true of course that Ankersmit and Runia's theories are aimed against this movement. Nevertheless, this does not mean that they should throw the baby out with the bathwater. If their aim is to create a new paradigm, they should try to incorporate this accomplishment of the post-structuralist paradigm. If not, their theories are open to the (justified) criticism of being nationalist, imperialistic and selfcentered. In what follows from here, I will argue that Ankersmit and Runia's theories are indeed limited to history as a matter of identity, excluding the otherness of the past.

\subsection{Identity in Ankersmit}

Let us first look at Ankersmit's second version of historical experience, namely sublime historical experience. As already said, Ankersmit considers sublime historical experience to be a special kind of trauma, trauma2, where no reconciliation is possible. The sublimity of this kind of experience consists in the combination of a longing for the past and the realization that this past will never come back. What is important here is that this revolves around matters of identity. Sublime historical experience is always an experience of the lost identity of a community. (Ankersmit 2001b, 295) This entails that if the historian does not feel part of the lost community, there can be no historical experience. One cannot lose what one never had. Therefore, the object of sublime historical experience is limited to those groups one identifies with, which means that the experience of the Other is excluded, and which brings sublime historical experience dangerously close to nationalistic historiography.

This becomes even more clear when we ask ourselves the question whether the three examples given above might allow a sublime historical experience. The answer is clearly no. The point of exotic tourism is exactly to experience the life of communities and societies which one does not identify with. (cf. supra) The point of both microhistory and postcolonial and gender history is to reveal aspects and people of the past which have gone unnoticed until now. In the case of microhistory, these people are individuals in contingent historical situations, while in postcolonial and gender history we deal with groups of people in recurring and structural situations. The reason why the "others" of microhistory have fallen between the nets of history is that the traits they exemplify are not a part of the current-day identity of a certain social group. The "others" studied in postcolonial and poststructural history on the 
other hand do have a common identity in the present, but one which has never been part of the identity of a civilization. As Ankersmit makes clear by stating that sublime historical experience is about the fall of civilizations, postcolonial history-writing is a priori excluded from sublime historical experience.

As a second point, we should take a look at the Huizinga-type of historical experience, or, to speak in Huzinga's own terms, historical sensation. This seems more promising. Huizinga nor Ankersmit when talking about Huizinga make references to an identification of the historian with the past. Nevertheless, there is one major obstacle. In Huizinga's account, historical sensation can only be aroused by material objects and not by means of historical writing. As we have seen, this is a necessary component of Huizinga's concept of historical sensation, since it is, the only way in which the past can come to us in a non-representational way. This entails that historical sensation can only account for (part of) the first of the three examples given above. It is not applicable to experiences aroused by, or on the basis of, reading historical works such as, for example, Montaillou or The Return of Martin Guerre. Therefore, if the concept of historical sensation can capture our scientific dealings with history, it can only do so in a limited way. It is a privilege of practicing historians who deal with the real material, such as the documents themselves, the materials and the witnesses, and it can never be transferred to the audience which reads their books. Therefore, historical sensation is an elitist notion, limited to the elite of practicing (professional) historians.

\subsection{Identity in Runia}

As we have seen, Runia's theory has two aspects. The first is passive. It is concerned with the effect the past has on us. Runia calls this "presence. The second, sublime historical action, is active. As we have seen, the latter aspect is largely methodological, which means that we can leave it aside for now and focus on Runia's notion of "presence". The question is: is the notion of presence bound exclusively to the subject which undergoes presence? Is it possible to experience the "presence of the other"? As we have seen, the definition of presence goes as follows. "Presence," in my view, is "being in touch"- either literally or figuratively
— with people, things, events, and feelings that made you into the person you
are. It is having a whisper of life breathed into what has become routine and
clichéd—it is fully realizing things instead of just taking them for granted.
$(2006 \mathrm{~b}, 5)$

It is quite clear that the concept of presence is linked to identity. Presence is the experience of those things that have constituted our identity, that made us into the persons we are. Being constitutive of our identity is a necessary condition for something to create a sensation of "presence". Something which has not made me into what I am, such as the events in Montaillou in the beginning of the $14^{\text {th }}$ century, cannot have a presence-efffect. Therefore, any experience of the other, the past as we have never known or lived it, is out of the question. This is very clear in the case of 
the historians of the Srebrenica commission installed by the NIOD (Dutch Institute for War Documentation) Runia repeatedly states that it was the identification of the NIOD historians with the Dutch battalion they investigated which led to the acting out (and the presence) of the past. (Runia 2004, 309-315) Without identification, there can be no parallel processing, and by extension no presence of the past. In fact, Runia even seems to suggest that the otherness of the past is simply opposed to presence. In (Runia 2007), he states that the more we commemorate, i.e. the more we represent, the more we constitute the past as other.

Fifth thesis: the more we commemorate what we did, the more we transform ourselves into people who did not do it. (Runia 2007, 320)

Runia's general idea in (Runia 2007) is that a direct contact with our past is to horrifying to deal with, and that we solve this problem with the help of commemoration. The symbolizing and representational practices of commemoration turn the past into the other, something which is not linked anymore to our own identity and therefore not threatening. Therefore, if the Other figures at all in Runia's theory, it is only as a decoy which draws attention away from a more fundamental way of dealing with the past. If we analyze our three examples using Runia's theory, we can only conclude that the attention given to the otherness of history is only secondary to a more important way of relating to the past, namely the realization that events in the past have shaped our own identity in a more fundamental way than we would like to believe.

This again becomes more clear when we ask ourselves the question whether it would be possible to speak of a presence-effect aroused by, or on the basis of, exotic tourism, micro-history or postcolonial history. In the case of tourism, the answer is quite obviously no. Runia talks at length about the phenomenon of tourism, (which he believes to stem from the desire to commemorate) and he makes it very clear that this desire only arises with people who are concerned with something which they perceive as their past, the past of their family, their nation, their class,.... Four of Runia's ten theses about commemoration explicitly mention notions of identity, referencing to our past and the question who we are. (Runia 2007, 316, 317, 320, 325) With regard to micro-history, there is a similar problem. Given the fact that the aim of micro-history is to bring the outsiders to the front row and show the strangeness and the otherness of the past, micro-history is probably the least open to identification of all possible kinds of history-writing. Provided a historiographical work could have a presence effect it would certainly not be a micro-historical work, but rather a work in which a historian studies the same social group as she himself belongs to, as was the case in the Srebrenica report.

\subsection{The alternative}

We have seen that Frank Ankersmit and Eelco Runia have taken up the challenge of developing a theory which allows us to speak about the past itself without resorting to naïve realism. Both do this by turning away from knowledge and representation to a 
more direct and experiential contact with the past. Nevertheless, it has become clear that Runia nor Ankersmit can account for a kind of experience of the past which is of great importance in Western historical thinking, or rather, Western historical "experiencing": the experience of the past as the Other, or the topos of "the past is a foreign country". It is this kind of experience which lies at the source of three important historical traditions and directions in the West. Because of this, we are in need of a different theory of historical experience which can account for these phenomena based on the experience of the Other. I will not pretend to offer such a theory here. I will merely suggest that we do not have to start from scratch. If we want a theory of the experience of the Other in history, we can come quite far by starting from the ethical phenomenology of Emmanuel Levinas. Of course, there is the obvious point that his theory of the experience of the Other does not involve identification and allows for a genuine account of the encounter with the Other as Other. Besides this, however, I will give four additional arguments which support the thesis that Levinas' ethical phenomenology could form the basis for a theory of the experience of the otherness of the past.

In particular, there is one feature which immediately jumps to mind. Levinas makes a distinction between experience and perception. (for a discussion of these terms, see Barata 2008) The term perception refers to the traditional form of empirical input as described in the empiricist tradition and in Husserlian phenomenology. The aim of this kind of perception is to integrate the outside world into the self or, to speak in Kantian terms, to force nature into behaving according to our own laws. Confusingly enough, this is what Kant himself calls Erfahrung, or "experience". So when Levinas talks about "perception" he means what Kant denotes with the term "experience". The subject which perceives, the atheist I, is an active, intentional subject, an Ego, which can only find itself in the other and whose identity is never fully at stake. (see Levinas 1971, 45-53) This type of subjectivity is of the kind Ankersmit and Runia criticize and to which their theories are a reaction. On the other hand, Levinas states that there is a more fundamental notion called experience, which is totally different.

Experience in the Levinasian sense is an experience of the radically Other. In our experience of the Other, the subject is a passive one. (for example Levinas 1978a, 3031) We cannot anticipate the Other, and we cannot force him into predetermined categories. The Other is always an unexpected guest, who does not contribute to our life in a strictly practical or intellectual sense but who draws our attention nonetheless. This attention is, according to Levinas, based on the notion of responsibility, an intentional relationship with the Other which is not rooted in scientific or economical motives but which finds its source in an inexplicable curiosity and fascination for other persons. (Levinas 1971, 194) Levinas' distinction between perception and experience is very similar to Ankersmit's distinction between representation and experience and Runia's distinction between representation and presence. Just as Runia and Ankersmit, Levinas allows us to talk about a kind of contact of the past which is not limited to representational schemes. The reason is that the essence of the experience of the Other is precisely that it breaks through these schemes. 
Second, Levinas explicitly states that the experience of the Other is always an anachronistic experience. (Levinas 1978b, 22-24) Perception and cognition are, according to Levinas, synchronizing activities. They attune the outside world to our economical interests and our general cognitive world view, to our memories and expectations or, in the terms of Reinhart Koselleck, to our space of experience and our horizon of expectations. (see Koselleck 2004, 255-276) As we have seen, the Other breaks through this synchronicity. He has the potential to change our look at the future and the past. The Other always comes from a different time, he has different expectations, different memories. Because we have an ethical responsibility towards the Other, we have to take these into account, which results in an experience of diachronicity, the existence of different times at the same moment within the same subject.

So what do we have now? At this point, we have a theory which accounts for the experience of the Other. An experience which is open for an application to history, since the Other is anachronistic by definition. Furthermore, Levinas already gives some hints into how his theory could be applied to history. He explicitly states that historical sources can serve as "traces" to the Other in the past. (Levinas 1972, 57-63) Diachronicity is therefore not limited to the Other in the present who holds different hopes and memories, but also in a more radical way to the Other in the past itself, whom we can still encounter as Other through historical sources. This suggest that Levinas' theory is indeed suitable for an analysis of the experience of the otherness of the past as described in the three examples given above

As a fourth point, Levinas does not believe in a trade-off between representation or language on the one hand and the experience of the Other on the other hand. He states that language is a condition of possibility of the experience of the Other. (see for example Levinas 1971, 224-228) The point, however, is that not all use of language is the same. Levinas points to the difference between saying and the said. (Levinas 1978a, 43-44) The said is the discourse of science and perception. What is said is fixed and totalizing: it forces experience into the discourse of language. This is the kind of practice Ankersmit and Runia criticize in their objections against representation. However, Levinas argues that the said has its source in the intentional act of saying, which implies an intentionality towards the Other. All communication has its base in the will to talk and listen to the Other, which in its turn has its roots in the experience of the otherness of the Other. Because of this double account of language, it is possible to see certain uses of language as creating an experience or a "presence-effect", while other uses, such as the ones described by narrativism, can be aimed more at a more representational effect. (see also Gumbrecht 2006; Barthes 1968) Therefore, it is, at least in principle, possible to do a Levinasian reading of micro-history and postcolonial/gender history and to give a theoretical account of the experience (and not the representation) of the Other which is aroused by these works.

As already said, these four points of consideration are merely a starting point. Nevertheless, they point to the possibility of a theory of the presence of the past which is not confined to identity, to the possibility of experiencing a past which is not our 
past. Therefore, I believe there is a wealth of undiscovered potential for philosophy of history in the philosophy of Emmanuel Levinas

\section{Summary}

I have given a critical comparison between the theories of Frank Ankersmit and Eelco Runia, with special regard to their conceptions on the subjectivity, the object and the language of history. Both have taken up the same challenge: to find a way in which we can talk about the past itself without falling in the trap of naïve realism. For both, the key lies in the idea of the presence of the past as a "presence in absence". The past is overwhelmingly present, not despite, but precisely because it is absent from our representational categories. We have also seen that there are two major differences. First, for Ankersmit, the past itself is essentially good, something of a lost paradise. For Runia, on the other hand, the past is absurd and horrifying. Second, while for Runia there is a quite rigourous trade-off between presence and representation, this relation is more nuanced in Ankersmit's account. Finally, I have argued that for both Ankersmit and Runia, the presence of the past is always a matter of identity. We can only experience the presence of a past which, in some way or other, is our past. I have argued that this entails that Ankersmit nor Runia can account for the otherness of the past, exemplified in three traditions which have been important in the way we in the West have dealt with history: exotic tourism, micro-history and post-colonial and gender history. I have suggested that a theory which can deal with an experience of the otherness of the past can be built on the philosophy of Emmanuel Levinas

\section{Acknowledgments}

This Research has been supported by FWO (FWO09/ASP/141). I would like to thank Berber Bevernage, Gertrudis Van de Vijver, Herman Paul, Alun Munslow, Brian Fay and two anonymous referees for their supportive criticisms of this paper.

\section{Notes on Contributor}

Anton Froeyman is currently preparing a Phd on Levinas and History at the centre for Critical Philosophy at Ghent University, Belgium, under the supervision of professor Gertrudis Van de Vijver.

\section{References}

Abbott, A. 2007. Against narrative: a preface to lyrical sociology.

Sociological Theory 25 no. 1: 67-99.

Agnew, V. 2007. History's affective turn. Historical reenactment and its work in the present. Rethinking History, 11 no. 3: 299-312.

Alexander, Z. Bakir, A. and Wickens, E. 2010. An investigation into the impact of vacation travel on the tourist. International Journal of Tourism Research 12 no. 5: 574590.

Ankersmit, F. 1983. Narrative logic. A semantic analysis of the historian's language. Den Haag: Nijhoff.

Ankersmit, F. 1993. De historische ervaring. Groningen: Historische Uitgeverij 
Groningen.

Ankersmit, F. 1996. Can we experience the past?. in Veit-Brause, Imline \&

Thorstendahl, Rolf, History-making: the intellectual and social formation of a

discipline, Stockholm: Coronet Books: 47-77.

Ankersmit, F. 2000. Representation as the representation of experience. Metaphilosophy 31, no. 1/2, 148-169.

Ankersmit, F. 2001a. Historical representation. Stanford: Stanford University Press.

Ankersmit, F. 2001b, The sublime dissociation of the past, or: how to become what one is no Longer. History and Theory 40, no. 3: 295-323.

Ankersmit, F. 2005. Sublime historical experience. Stanford: Stanford University Press.

Ankersmit, F. 2007. De Sublieme historische Ervaring, Groningen: Historische Uitgeverij,

Barata, A. 2008. Levinas, Husserl and Damasio - From otherness as experience to experience of otherness. Estudos e Pesquisas Em Psicologia 8, no. 2: 204-212.

Barthes, R. 1968. L'effet du Réel. Communications 11: 84-89.

Bentley, M. 2006. Past and presence: revisiting historical ontology. History and Theory 45 no. 3: 349-361.

Cohen, E. 2004. Contemporary tourism: diversity and change. Boston: Elsevier, 2004.

Culler, J. 1989. Framing the sign: criticism and its institutitons. Malden: Blackwell.

Evans, D. 1996. An Introductory dictionary of Lacanian psychoanalysis. London:

Routledge.

Gumbrecht, H. U. 2003. The powers of philology. Dynamics of textual scholarship. Urbana and Chicago: University of Illinois Press.

Gumbrecht, H. U. 2004. Production of presence. What meaning cannot convey. Stanford: Stanford University Press.

Gumbrecht, H. U. 2006. Presence achieved in language (with special attention given to the presence of the past). History and Theory 45, no.3: 317-327.

Godzich, W. 2010. Foreword: the further possibility of knowledge. in De Certeau, Michel, Heterologies, translated by Brian Massumi, London: University of Minnesota Press London: vii-xxi.

Huizinga, J. 1948-1953. Verzamelde werken Volume II. Haarlem: Tjeenk Willink,. (referred to as Huizinga II)

Huizinga, J. 1948-1953. Verzamelde werken Volume VII. Haarlem: Tjeenk Willink, (referred to as Huizinga VII)

Icke, P. 2010, Frank Ankersmit's 'narrative substance': A legacy to historians. Rethinking History 14 no.4: 551-567.

Jenkins, K. 2008a. Cohen contra Ankersmit. Rethinking History 12, no. 4: 537-555.

Jenkins, K. 2008b. 'Nobody does it better': radical history and Hayden White. Rethinking History 12, no. 1: 59-74.

Jenkins, K..2008c. Sande Cohen: on the verge of newness. Rethinking History 12, no. 4 : 437-462.

Jones, A. 2000. Word and deed: why a post-poststructural history is needed and how it might look. The Historical Journal 43, no. 2: 517-541.

Jones, A. 2007. Reporting in Prose: Reconsidering Ways of Writing History. The European Legacy 12, no. 3: 311-336.

Jones, A. 2008. Vivid history: existentialist phenomenology as a new way to understand an old way of writing history, and as a source of renewal for the writing of history, Storia della Storiografia 54: 21-56. 
Koselleck, R. 2004. Futures past. On the semantics of historical time. Translated and with an introduction by Keith Tribe. New York: Columbia University Press.

Levinas, E. 1971. Totalite et infini, The Hague: Martinus Nijhoff.

Levinas, E. 1978a. Autrement qu'ëtre, The Hague: Martinus Nijhoff.

Levinas, E. 1978b. De l'existance à l'existant, Paris: Librairie Philosophique.

MacCannel, D. 1999. The tourist: a new theory of the leisure class, Berkeley,

University of California Press.

Moskalewicz , M. 2007. Sublime experience and politics: an interview with professor Frank Ankersmit, Rethinking History 11 no. 2: 251-274.

Palti, E. 2004. The 'return of the subject' as a historico-intellectual problem. History and Theory 43, no. 1: 57-82.

Peillon, M. 1984. Tourism: a quest for otherness, The Crane Bag 8, no. 2: 165-168.

Philips, M. S. 2008. On the advantage and disadvantage of sentimental history for life.

History Workshop Journal 65, no. 1: 49-64.

Runia, E. 1995. De pathologie van de veldslag: geschiedenis en geschiedschrijving in

Tolstoj's Oorlog en Vrede. Amsterdam: Meulenhoff.

Runia, E. 1999. Waterloo, Verdun, Auschwitz.De liquidatie van het verleden. Amsterdam:

Meulenhoff.

Runia, E. 2004. Forget about it: 'parallel processing' in the Srebrenica report. History and Theory 43, no. 3: 295-320.

Runia, E. 2006a. Namen noemen. Tijdschrift voor Geschiedenis 119: 242-248.

Runia, E. 2006b. Presence. History and Theory 45, no. 1: 1-29.

Runia, E. 2006c. On presence: spots of time. History and Theory 45, no. 3: 305-316.

Runia, E. 2007, Burying the dead, creating the past. History and Theory 46, no. 3: 313325.

Runia, E. 2010, Into cleaness leaping: the vertiginous urge to commit history, History and Theory 49, no. 1: 1-20.

Szijarto, I. 2002. Four arguments for microhistory, Rethinking History 6, no. 2, 209-215. 